Agro-Science Journal of Tropical Agriculture, Food, Environment and Extension Volume 11 Number 2 May 2012 pp 54 - 61

ISSNTIIY-7455

\title{
LABLAB EFFECT ON SOIL PROPERTIES AND SUBSEQUENT MAIZE-COWPEA INTERCROP
}

\author{
Ewansiha $^{1}$ S. U., Ogedegbe ${ }^{1}$ S. A. and Chiezey ${ }^{2}$, U.F. \\ ${ }^{1}$ Department of Crop Science, Faculty of Agriculture, University of Benin, PMB 1154, Benin City, \\ Nigeria. \\ ${ }^{2}$ Department of Agronomy, Faculty of Agriculture, Ahmadu Bello University, PMB 1044, Zaria, Nigeria \\ *Corresponding author: sylvester.ewansiha@uniben.edu
}

\begin{abstract}
The ability of herbaceous legumes to supply nitrogen to subsequent cereal crops could be harnessed to alleviate the difficulties in cereal production due to poor soil fertility and expensive inorganic fertilizers. Field experiments were carried out in Zaria, Nigeria to determine the soil improvement potential of Lablab purpureus accessions and evaluate the grain and fodder response of maize-cowpea intercrop to one-year fallow rotation. Six lablab accessions (ILRI 147, ILRI 4612, PI 388013, PI 183451, PI 195851 and PI 532170) of different maturity groups and natural vegetation represented the fallow treatments. The maize and cowpea test crops were TZE Comp.5 W and IT99K-241-2, respectively. Lablab fallow improved soil organic carbon, nitrogen, phosphorus and potassium. The early maturing PI 388013 increased phosphorus and potassium by 179 and $100 \%$, respectively whereas extremely late maturing PI 195851 increased nitrogen by $18 \%$ while another early maturing accession PI 183451 increased organic carbon by $11 \%$ relative to natural fallow. Lablab grain and fodder yields ranged from 0.6 to $1.4 \mathrm{tha}^{-1}$ and 2.4 to $3.9 \mathrm{t} \mathrm{ha}^{-1}$, respectively. Compared to natural fallow, intercropping maize on plots previously planted to ILRI 4612 led to significantly higher fodder yield $\left(2.8\right.$ to $\left.4.1 \mathrm{t} \mathrm{ha}{ }^{-1}\right)$ meaning an increase of $46 \%$. Lablab or natural fallow did not influence grain yield and 500-seed-weight of maize; it did not also influence 100-seed-weight, grain and fodder yields of cowpea. The fallow period for lablab may not have been long enough for significant improvement of soil properties to impact maize and cowpea performance in relation to natural fallow. The study showed that a maize-cowpea intercrop following lablab in rotation can be of rational inclusion in the farming system of the zone.
\end{abstract}

Keywords: lablab, intercropping, maize, cowpea, soil properties.

\section{INTRODUCTION}

Lablab (Lablab purpureus [L.] Sweet), a multi-purpose legume used for food, fodder, soil improvement, soil protection and weed control (Ewansiha et al., 2007), may be grown as a component crop in mixed farming systems (NAS, 1979). In northern Nigeria, lablab provides food for humans, fodder for livestock and income from the sale of grains and fodder (Bhat and Etejere, 1985; Thomas and Sumberg, 1995; Iwuafor and Odunze, 2000; Adeoye and Onifade, 2000). Ewansiha et al., 2008, opined that increasing use of lablab within the mixed croplivestock farming systems would increase the availability of livestock feed, while improving soil fertility and providing food for the people at the same time from the same piece of land. Cowpea (Vigna unguiculata [L.] Walp.) is a major component of the traditional cropping systems in Africa, Asia, and Central and South America where it is widely grown in mixtures with other crops in various combinations (Olufajo and Singh, 2002). Maize (Zea mays L.) which is the most important cereal crop in sub-Saharan Africa (IITA, 2006), is rapidly replacing millet (Pennisetum glaucum L.) and sorghum (Sorghum bicolor L. Moench) as the staple grain crop in the northern Guinea savanna (Fakorede et al., 2003; Kamara et al., 2005). Maize, millet and sorghum are commonly grown in intercrop combinations with cowpea (Stoop, 1986; NAERLS and NPAFS, 2010).

Low soil fertility is among the key factors affecting cowpea intercrop productivity (Olufajo and Singh, 2002). Nitrogen is the most limiting nutrient in maize production in the savannas of West and Central Africa (Carsky and Iwuafor, 1995). The high price of inorganic fertilizer and poor access by farmers are 
constraints to $\mathrm{N}$ fertilizer use among farmers in the sub-region (Smith et al., 1997; Akintoye et al., 1999). One strategy that may help in improving the productivity of maize-cowpea intercrop under low soil fertility is to combine the use of residual nitrogen from nitrogen fixing legumes and inorganic fertilizer. Previous studies (Cheruiyot et al., 2001; Ewansiha et al., 2008) showed that soil $\mathrm{N}$ status and yield of maize improved following the growing and incorporation of lablab residues. Adding $\mathrm{N}$ fertilizer to plots formerly grown to lablab enhanced the productivity of subsequent maize. However, no information exists on the effect of lablab on maize-cowpea intercrop even with added nitrogen fertilizer. This information is desirable in order to establish the productivity of cereal-legume intercropping system under the combined use of legume fallow and low rate of nitrogen fertilizer. This study was therefore conducted to determine the soil improvement potential of lablab accessions and evaluate the grain and fodder response of intercropped maize and cowpea to lablab fallow.

\section{MATERIALS AND METHODS Experimental site}

Field studies were conducted during the 2008, 2009 and 2010 growing seasons (June-November) at Samaru, Zaria in the northern Guinea savanna of Nigeria $\left(11^{\circ} 11^{\prime} \mathrm{N}\right.$ latitude, $7^{\circ} 38^{\prime} \mathrm{E}$, longitude; $686 \mathrm{~m}$ asl) on a sandy loam classified as alfisols with basement complex parent material. Rainfall is monomodal, starting in May and ending in October with an average rainfall of $1000 \mathrm{~mm}$. The zone has a growing period of 151-180 days, with a daily mean temperature of $20^{\circ} \mathrm{C}$ during the growing season. The rainfall and temperature during the trial period are summarized in Table 1.

\section{Plant materials, treatments and experimental design}

A total of six lablab accessions (PI 388013, very early maturing, PI 183451, early maturing, PI 532170, intermediate maturing, ILRI 147, late maturing, ILRI 4612, very late maturing, and PI 195851, extremely late maturing) as identified by Ewansiha (2002) were evaluated in the study. These accessions were initially obtained from Texas A \& M University, and International Livestock Research Institute (ILRI), Addis-Ababa, Ethiopia. At the time of their evaluation in this trial, they have been multiplied severally in Nigeria. Maize variety intercropped with cowpea was early maturing TZE Comp. $5 \mathrm{~W}$; the cowpea variety was late maturing IT99K-241-2. The maize and cowpea varieties were obtained from the International Institute of Tropical Agriculture (IITA), Ibadan, Nigeria. The experiment was laid out as a randomized complete block design with four replications. The treatments consisted of the lablab accessions and a weedy control. Each treatment plot measured $3 \times 5 \mathrm{~m}$ and consisted of four rows with 0.75 $\mathrm{m}$ spacing between rows.

\section{Agronomic practices}

In 2008, the trial field was disc-harrowed following vegetation kill with paraquat (1:1-dimethyl4, 4-bipyridinum dichloride). The trial field was divided into two portions, $\mathrm{A}$ and $\mathrm{B}$. The lablab fallow was established on portion A in 2008 and on portion B in 2009. The plots were hand-ridged using hoes. Three seeds of the lablab accessions were planted at a spacing of $20 \mathrm{~cm}$ within row at a depth of $2-4 \mathrm{~cm}$. The seeds were planted on 18 July in 2008 and 29 June in 2009. At planting, the experiments received a basal application of SSP at a rate of $30 \mathrm{~kg} \mathrm{P} \mathrm{ha}^{-1}$. Seedlings were left un-thinned. Insecticide, karate $(50 \mathrm{~g} / 1$ lambdacyhalothrin manufactured by Syngenta Crop protection AG, Switzerland) mixed with Nugor $(40 \%$ w/v dimethoate manufactured by United Phosphorus Limited, India), was applied thrice at a rate of one litre $\mathrm{ha}^{-1}$ to control insect pests. Weeds were controlled by hoe-weeding at three and six weeks after planting (WAP). In 2009 and 2010, maize was planted to all lablab and weedy treatment plots of the previous year. Lablab residues or weeds were evenly spread and incorporated at ridging. Maize was planted on 20 June in 2009 and on 19 June in 2010. Three seeds of maize were planted at a spacing of $25 \mathrm{~cm}$ within row at a depth of 2-4 cm. Seedlings were thinned to one plant stand $^{-1}$ at two WAP. At planting, the experiments received a basal application of NPK 15:15:15 at a rate of $30 \mathrm{~kg} \mathrm{~N}, \mathrm{P}$ and $\mathrm{K} \mathrm{ha}{ }^{-1}$. At three WAP, urea was sidedressed to provide nitrogen at a rate of $30 \mathrm{~kg} \mathrm{ha}^{-1}$. Weeds were controlled by hoe-weeding at three and five WAP. At six WAP, cowpea was introduced into the maize when earthening-up was done. Three cowpea seeds were planted half-way between two stands of maize within row and seedlings were thinned to two plants stand ${ }^{-1}$ at two WAP. Similar to lablab, insect pests were sprayed thrice with karate $(50 \mathrm{~g} / \mathrm{l}$ lambdacyhalothrin manufactured by Syngenta Crop protection AG, Switzerland) mixed with Nugor $(40 \%$ w/v dimethoate manufactured by United Phosphorus Limited, India) at a rate of one litre ha ${ }^{-1}$. A single hoeweeding was carried out just before flowering began. Lablab and cowpea were harvested when pods have turned fully brown and dried while maize was harvested when cobs turned brown and leaves were dried. 


\section{Data collection}

Temperature and rainfall data were obtained from the Institute of Agricultural Research (IAR) Agro-Meteorological Station located near the experimental plot. At the onset of the experiment, initial soil samples were collected randomly across the experimental field at $0-25 \mathrm{~cm}$ soil depth using soil auger. The soil samples were bulked and a composite sample was taken. In 2009 and 2010, just before maize was planted, soil sample was taken from each treatment plot. The soil samples were bulked according to each treatment and composite sample was taken. All composite samples were dried, ground and sieved using a $1 \mathrm{~mm}$ sieve. The composite samples were taken to the Analytical Services Laboratory (ASLAB) of IITA for the determination of soil $\mathrm{pH}$, organic carbon $(\mathrm{OC})$, total $\mathrm{N}$, extractable $\mathrm{P}$, and exchangeable $\mathrm{K}$ following standard procedures (IITA, 1982).

Field data were collected from the two middle rows leaving the outside rows. At maturity, lablab and cowpea pods were harvested, air-dried for two weeks and shelled. Grains were weighed and expressed in $\mathrm{kg}$ $\mathrm{ha}^{-1}$, adjusted to $14 \%$ moisture content using Dickeyjohn grain moisture tester. The fodder was rolled up and left in the plot to dry. When constant weight was achieved, fodder was weighed and calculated in $\mathrm{kg}$ ha 1 . Mean 100-seed weight was recorded for each plot. For maize, ears were removed, air-dried for one week and shelled. Grains were weighed and expressed in $\mathrm{kg}$ $\mathrm{ha}^{-1}$, adjusted to $12 \%$ moisture content using Dickeyjohn grain moisture tester. Each plot stover (stem, leaf, and husk) was sun-dried to a constant weight on the field, weighed and expressed in $\mathrm{kg} \mathrm{ha}^{-1}$. Mean 500-seed weight was recorded for each plot.

\section{Data analysis}

Statistical analysis was performed using SAS for Windows Release 9.2 (SAS Institute, 2008). The SAS procedure used for the ANOVA was Generalized Linear Model (GLM). Means procedure in the SAS programme with the option Duncan (for Duncan's multiple range test) was used in separating the means of the main effects. Variability of means is presented as standard error (s.e.) at 5\% test of significance. The analysis was done over the two years due to non-significant interactions.

\section{RESULTS \\ Growing conditions}

The soils utilized in the current study were well-drained, sandy-loam with mean $\mathrm{pH}$ of 5.1. Rainfall in the three years of experimentation was higher than the mean for the zone being 1140, 1278 and $1127 \mathrm{~mm}$ in 2008, 2009 and 2010 respectively (Table 1). Mean maximum and minimum temperatures during the growing seasons were 32.1 and $19.3^{\circ} \mathrm{C}$ respectively.

\section{Soil properties}

The soil properties before and after lablab are presented in Table 2. Organic carbon and nitrogen contents of the natural fallow deteriorated after cropping whereas $\mathrm{P}$ and $\mathrm{K}$ contents increased although not to the extent recorded by lablab accessions. On average, there were increases in soil properties due to lablab for OC (7 \%), N (10\%), P (68\%) and K (13\%). Highest increases were recorded in plots previously planted to PI 183451 for OC (11\%), PI 195851 for $\mathrm{N}$ (18\%) and PI 388013 for P and K (179 and $100 \%$, respectively).

\section{Grain yield, 100-seed-weight and fodder yield of lablab accessions \\ Grain yield, 100-seed-weight and fodder yield} of lablab accessions are presented in Table 3. Lablab accessions ILRI 147 and PI 183451 produced similar grain yields which were significantly higher than those obtained from ILRI 4612, PI 195851, PI 388013 and PI 532171. Significant differences did not occur among these other accessions in grain yield. The 100-seedweight of lablab ranged from 16.5 to $22.1 \mathrm{~g}$. ILRI 147 and PI 183451 produced seeds that were significantly heavier than those of PI 388013 and PI 532170. Accessions PI 388013 and PI 532170 had the lightest seeds. Fodder yields of ILRI 147, ILRI 4612 and PI 532170 were similar but significantly higher than those of PI 195851, PI 388013 and PI 183451. Lowest fodder yield was obtained from natural fallow plot when compared with the lablab accessions 
Table 1. Rainfall and temperature at Samaru during the experimental period

\begin{tabular}{|c|c|c|c|c|c|c|c|c|c|}
\hline \multicolumn{4}{|c|}{2008} & \multicolumn{3}{|l|}{2009} & \multirow{2}{*}{\multicolumn{3}{|c|}{2010}} \\
\hline \multirow[b]{3}{*}{ Month } & \multirow[b]{3}{*}{$\begin{array}{l}\text { Rainfall } \\
(\mathrm{mm})\end{array}$} & & & & & & & & \\
\hline & & \multicolumn{2}{|c|}{ Temperature $\left({ }^{\circ} \mathrm{C}\right)$} & \multirow[b]{2}{*}{ Rainfall (mm) } & \multicolumn{2}{|c|}{ Temperature $\left({ }^{\circ} \mathrm{C}\right)$} & \multirow[b]{2}{*}{$\begin{array}{l}\text { Rainfall } \\
(\mathrm{mm})\end{array}$} & \multicolumn{2}{|c|}{ Temperature $\left({ }^{\circ} \mathrm{C}\right)$} \\
\hline & & $\min$ & $\max$ & & $\min$ & $\max$ & & $\min$ & $\max$ \\
\hline January & 0 & 13.6 & 29 & 0 & 14.1 & 33.8 & 0.0 & 13.4 & 33.8 \\
\hline February & 0 & 15.7 & 32 & 0 & 16.9 & 36.3 & 0.0 & 17.4 & 37.1 \\
\hline March & 0 & 19.9 & 38.6 & 0 & 19.6 & 38 & 0.0 & 21.1 & 37.2 \\
\hline April & 72.6 & 21.8 & 37.4 & 20.3 & 23.2 & 38.4 & 52.4 & 22.8 & 38.5 \\
\hline May & 95.2 & 21.9 & 35 & 85.1 & 22.2 & 35.5 & 92.9 & 22.7 & 35.4 \\
\hline June & 111.7 & 20.9 & 33.1 & 89.5 & 21 & 33.2 & 158.3 & 20.6 & 32.6 \\
\hline July & 201.3 & 20 & 30.5 & 285 & 20 & 32.3 & 216.8 & 19.4 & 30.3 \\
\hline August & 352.6 & 19.5 & 29.7 & 439.7 & 20.4 & 30 & 313.4 & 20.1 & 29.8 \\
\hline September & 217.5 & 25.5 & 31.4 & 206.7 & 20 & 31.9 & 211.2 & 20.9 & 31.2 \\
\hline October & 89 & 18.2 & 33.2 & 151.7 & 20.3 & 32.8 & 82.3 & 20.6 & 32.6 \\
\hline November & 0 & 12.8 & 33.8 & 0 & 14.8 & 32.4 & 0.0 & 16.2 & 33.7 \\
\hline December & 0 & 14.6 & 32.1 & 0 & 13.3 & 33.5 & 0.0 & 12.6 & 31.8 \\
\hline Total & 1139.9 & & & 1278 & & & 1127.0 & & \\
\hline
\end{tabular}

Table 2. Lablab effects on subsequent soil pH, OC, total $N$, extractable $P$, and exchangeable $K$

\begin{tabular}{|c|c|c|c|c|c|}
\hline Treatment & pH( $\left(\mathrm{H}_{2} \mathrm{O}\right) 1: 1$ & $\mathrm{OC}\left(\mathrm{g} \mathrm{kg}^{-1}\right)$ & $\mathrm{N}\left(\mathrm{g} \mathrm{kg}^{-1}\right)$ & $P\left(\operatorname{ug~g}^{-1}\right)$ & $\mathrm{K}^{+} \mathrm{Cmol} \mathrm{kg}^{-1}$ \\
\hline Before Lablab & 5.1 & 5.5 & 0.50 & 3.4 & 0.23 \\
\hline \multicolumn{6}{|l|}{ After Lablab } \\
\hline ILRI 147 & 5.0 & 6.0 & 0.52 & 2.9 & 0.15 \\
\hline ILRI 4612 & 5.1 & 5.7 & 0.55 & 5.3 & 0.30 \\
\hline PI 195851 & 5.0 & 5.8 & 0.59 & 5.4 & 0.21 \\
\hline PI 388013 & 5.1 & 5.6 & 0.55 & 9.5 & 0.46 \\
\hline PI 183451 & 5.1 & 6.1 & 0.56 & 4.4 & 0.19 \\
\hline PI 532170 & 5.2 & 5.9 & 0.53 & 6.9 & 0.25 \\
\hline Natural fallow & 5.1 & 5.4 & 0.49 & 3.7 & 0.24 \\
\hline
\end{tabular}

Table 3. Grain yield, seed weight and fodder yield of lablab

\begin{tabular}{llll}
\hline Treatment & Grain yield $\left(\mathrm{kg} \mathrm{ha}^{-1}\right)$ & 100 -seed-weight $(\mathrm{g})$ & \\
\hline ILRI 147 & $1371.6 \mathrm{a}$ & $21.9 \mathrm{a}$ & Fodder yield $\left(\mathrm{kg} \mathrm{ha}^{-1}\right)$ \\
ILRI 4612 & $819.7 \mathrm{~b}$ & $18.9 \mathrm{abc}$ & $3872.0 \mathrm{a}$ \\
PI 195851 & $931.3 \mathrm{~b}$ & $20.3 \mathrm{ab}$ & $3852.0 \mathrm{a}$ \\
PI 388013 & $595.0 \mathrm{~b}$ & $17.6 \mathrm{bc}$ & $2490.0 \mathrm{~b}$ \\
PI 183451 & $1317.7 \mathrm{a}$ & $22.1 \mathrm{a}$ & $2412.0 \mathrm{~b}$ \\
PI 532170 & $939.7 \mathrm{~b}$ & $16.5 \mathrm{c}$ & $2554.0 \mathrm{~b}$ \\
Natural fallow & - & - & $3222.0 \mathrm{a}$ \\
Mean & 995.8 & 19.6 & $1492.4 \mathrm{c}$ \\
SE & 125.67 & 1.10 & 2842.1 \\
\hline
\end{tabular}

Mean values within each column having similar letter (s) in common are not significantly different at $5 \%$ level of probability according to Duncan Multiple Range Test.

Table 4. Lablab effects on grain yield, seed weight and fodder yield of subsequent intercropped maize

\begin{tabular}{llll}
\hline Treatment & Grain yield $\left(\mathbf{k g ~ h a}^{\mathbf{- 1}}\right)$ & $\mathbf{5 0 0}$-seed-weight $(\mathbf{g})$ & ${\text { Fodder yield }\left(\mathbf{k g ~ h a}^{\mathbf{- 1}}\right)}$ \\
\hline ILRI 147 & 3501.4 & 117.3 & $3141.4 \mathrm{ab}$ \\
ILRI 4612 & 3355.9 & 121.6 & $4072.4 \mathrm{a}$ \\
PI 195851 & 3568.9 & 124.3 & $3484.8 \mathrm{ab}$ \\
PI 388013 & 3433.7 & 112.0 & $3179.3 \mathrm{ab}$ \\
PI 183451 & 3494.8 & 123.3 & $3335.8 \mathrm{ab}$ \\
PI 532170 & 3111.4 & 117.3 & $3413.6 \mathrm{ab}$ \\
Natural fallow & 3001.4 & 110.0 & $2774.3 \mathrm{~b}$ \\
Mean & 3352.5 & 118.0 & 3343.1 \\
SE & & 368.07 \\
\hline
\end{tabular}

Mean values within each column having similar letter (s) in common are not significantly different at 5\% level of probability according to Duncan Multiple Range Test. 
Table 5. Lablab effects on grain yield, seed weight and fodder yield of subsequent intercropped cowpea

\begin{tabular}{llll}
\hline Treatment & Grain yield $\left(\mathbf{k g ~ h a}^{-\mathbf{1}}\right)$ & $\mathbf{1 0 0}$-seed-weight $(\mathbf{g})$ & Fodder $\mathbf{y i e l d ~}\left(\mathbf{k g ~ h a}^{\mathbf{- 1}}\right)$ \\
\hline ILRI 147 & 371.4 & 22.4 & 475.0 \\
ILRI 4612 & 331.4 & 21.6 & 458.3 \\
PI 195851 & 393.8 & 22.5 & 583.3 \\
PI 388013 & 297.8 & 21.7 & 483.3 \\
PI 183451 & 363.9 & 21.8 & 483.3 \\
PI 532170 & 370.2 & 21.2 & 600.0 \\
Natural fallow & 405.2 & 21.0 & 550.0 \\
Mean & 362.0 & 21.7 & 550.0 \\
\hline
\end{tabular}

\section{Grain yield, 500-seed-weight and fodder yield of maize}

Maize grain yield ranged from 3001.4 for fallow plot to $3568.9 \mathrm{~kg} \mathrm{ha}^{-1}$ for PI 195851 plot; significant differences did not occur among the treatments (Table 4). Similarly, significant differences did not occur among the treatments for 500-seed-weight. Five hundred-seed-weight ranged from 110.0 for natural fallow plot to $124.3 \mathrm{~g}$ for PI 195851 plot. Fodder yield was significantly higher for ILRI 4612 than for natural fallow. However, fodder yield was similar among other treatments.

\section{Grain yield, 100-seed-weight and fodder yield of cowpea}

There were no significant differences among the treatments for cowpea grain yield, 100-seed-weight and fodder yield (Table 5). Averaged over all treatments, cowpea grain yield was $362.1 \mathrm{~kg} \mathrm{ha}^{-1}, 100$-seed-weight $21.7 \mathrm{~g}$ and fodder yield $519 \mathrm{~kg} \mathrm{ha}^{-1}$.

\section{DISCUSSION}

The prevailing soil and weather conditions especially rainfall during the growing seasons were adequate for crop production. Ewansiha et al. (2008) reported that amount of rainfall can improve or adversely affect lablab performance depending on whether lablab is early or late maturing. According to Cheruiyot et al. (2001), maize is produced with high

rainfall (300-600 $\mathrm{mm})$ whereas lablab and cowpea are produced with the low rainfall (250 $-400 \mathrm{~mm}$ ) in Kenya.

Results showed that lablab can improve several soil properties at the same time. Organic carbon increased by 4-13\% in plots following lablab compared to natural fallow. Abunyewa and Karbo (2005) reported a higher organic content for pigeon pea (Cajanus cajan) and leucanea (Leucaena leucocephala) compared to a natural fallow system. Similarly, soil N increased by 6-20\% in plots following lablab compared to natural fallow. This finding is in agreement with previously reported values of 4$18 \%$ for legumes in northern Nigeria (Carsky et al., 1999). Among several legumes studied, Cheruiyot et al. (2001) reported highest increase in soil $\mathrm{N}$ in lablab plots, which was due to high residue quality. Ewansiha et al. (2007) reported up to $184 \mathrm{~kg} \mathrm{~N} \mathrm{ha}^{-1}$ for lablab shoot. The higher soil $\mathrm{P}$ and $\mathrm{K}$ obtained in plots planted to PI 388013 may indicate that this accession is better able to mine soil $\mathrm{P}$ and $\mathrm{K}$ from deeper soil horizons. Alternatively, decaying tissues of PI 388013 may have the potential to release more $\mathrm{P}$ and $\mathrm{K}$ than other lablab accessions. Again, PI 388013 may have utilized less the $\mathrm{P}$ that was previously applied to the lablab plots. Nonetheless, the ability of PI 388013 and ILRI 4612 to substantially improve soil P and K may be of practical significance. This may mean that when crops such as cowpea and maize with high $\mathrm{P} / \mathrm{K}$ requirement follow lablab in rotation, lesser amounts of these macro nutrients will be required.

Maize from plots previously grown to lablab had grain yields and seed weights that were not significantly different from those of natural fallow plots with no lablab. This finding did not however support earlier reports (Cheruiyot et al., 2001; Ewansiha et al., 2008). This may be due to the short fallow period of one year used in the present study compared with the two-year fallow reported by Ewansiha et al. (2008). This may mean that the one-year fallow period was not long enough for lablab to improve the soil for significant response by subsequent maize for these traits. In addition, the fodder yield of lablab was low compared to those earlier reported (Ewansiha et al., 2008). The soil improvement potential of lablab is related to the biomass (Cheruiyot et al., 2001).

Maize grain yields ranging from 3.0 $3.6 \mathrm{t} \mathrm{ha}^{-1}$ recorded in this study is below the potential maize grain yield (4 to $6 \mathrm{t} \mathrm{ha}^{-1}$ ) estimated for the region (Fakorede et al., 2003). Tarawali (1994), however, reported similar grain yield $\left(3.0 \mathrm{t} \mathrm{ha}^{-1}\right)$ for maize following legume fallow. Although not to a large extent, maize 
grain yield may have been reduced by intercropping. In a review involving maize and cowpea intercrop, Olufajo and Singh (2002) reported that maize grain yields were not affected by the cowpea component. On the other hand, maize yield following legumes will depend on the degree of $\mathrm{N}$ limitation (Muhr et $a l .$, 2002). Yields of maize might have improved if there where higher availability of $\mathrm{N}$.

Grain yield, seed weight and fodder yield did not vary among the treatments. Grain and fodder yields were low, averaging 0.4 and $0.5 \mathrm{t} \mathrm{ha}{ }^{-1}$, respectively. Low intercrop productivity has earlier been reported (Terao et al., 1997). Among the several reasons that have been advanced for the low productivity of intercropping systems is shading (Mortimore et al., 1997; Terao et al., 1997; Olufajo and Singh, 2002). The morphologically shorter component, usually cowpea, suffers greater yield reduction as a result of the shading effect of the taller cereal plants. Whenever intercropped cowpea affected maize, maize reduced cowpea yields more than the effect of cowpea on maize yields (Ofori and Stern, 1987) because of the greater competitive ability of maize when intercropped with cowpea.

The present study has shown that a maize-cowpea intercrop following lablab in rotation can be of rational inclusion in the farming system of the zone. Before this time, reported works on crop rotation has always been between two crops, for example, maize following soybean or cowpea or lablab. The present work has shown that a mixture of maize and cowpea can follow lablab. In this case, the soil is not only improved for the following crop, usually a cereal, but there is an enterprise diversity that yields both cereal and leguminous products. This contributes to the improvement of the livelihoods of the rural farmers in terms of better nutrition: the cereal provides their carbohydrate needs while the legume provides a cheap source of protein. The system also provides both cereal and leguminous fodder which ensures quality fodder for household animals.

\section{CONCLUSION}

Lablab fallows improved soil properties. Fallow treatments, lablab or natural, did not influence grain yield and seed weight of maize; it did not also influence seed weight, grain and fodder yields of cowpea whereas fodder yield of maize was significantly higher only in plots previously planted to ILRI 4612. The fallow period for lablab may not have been long enough for significant improvement of soil properties to impact maize and cowpea performance in relation to natural fallow. The maize-cowpea intercrop may have limited higher yield in cowpea. In future studies, in a short fallow that involves one year or season, higher lablab biomass should be aimed at by narrowing the spacing between two rows of lablab. This may help to achieve quicker soil improvement in the short period.

\section{ACKNOWLEDGEMENT}

The opportunity to use the research field of the Institute for Agricultural Research (IAR), Zaria, and the provision of meteorological data by the Soil Science unit of the Institute are gratefully acknowledged.

\section{REFERENCES}

Abunyewa, A. A. and Karbo, K. N. (2005). Improved fallow with pigeon pea for soil fertility improvement and to increase maize production in a small holder crop-livestock farming system in the sub-humid zone of Ghana. Land Degradation Development 16:447-454.

Adeoye, K. B. and Onifade, O. S. (2000). Cover crops adoption and forage seed production in Nigeria: report for the subhumid zone. In: Carsky, R.J., Eteka, A.C., Keatinge, J.D.H. and Manyong, V.M. (eds). Cover crops for Natural Resource Management in West Africa. Proceedings of a workshop held at Cotonou, Republic of Benin, 26-29 October 1999. International Institute of Tropical Agriculture: Ibadan, Nigeria. pp. 280-289.

Akintoye, H. A., Kling, J.G. and Lucas, E. O. (1999). N Use Efficiency of Single, Double and Synthetic Maize Lines Grown at 4-N Levels in Three Ecological Zones of West Africa. Field Crops Research 60: 189-199.

Bhat, R.B. and Etejere, E.O. (1985). Studies on the seed of Lablab niger Medic. Turrialba (ILCA) 35: 255-260.

Carsky, R.J. and Iwuafor, E.N.O. (1995). Contribution of Soil Fertility Research and Maintenance to Improved Maize Production and Productivity in SubSaharan Africa. In: Proceedings of Regional Maize Workshop, 29 May- 2 June, 1995, IITA, Cotonou, Benin Republic.

Carsky, R. J., Oyewole, B and Tian, G. (1999). Integrated soil management for the savanna zone of West Africa: Legume rotation and fertilizer N. Nutrient Cycling in Agroecosystems 55:95-105. 
Cheruiyot, E. K., Mumera, L. M., Nakhone, L. N and Mwonga S. M. (2001). Rotational effects of grain legumes on maize performance in the Rift Valley Highlands of Kenya. African Crop Science Journal 9(4): 667-676.

Ewansiha, S. U. (2002). Evaluation of Lablab purpureus (L.) Sweet for crop and forage production potential at Samaru in the northern Guinea savanna of Nigeria. Unpublished MSc. Thesis. Ahmadu Bello University, Zaria, Nigeria.

Ewansiha, S. U., Chiezey, U. F., Tarawali, S. A, and Iwuafor, E. N. O. (2007). Potential of Lablab purpureus accessions for crop-livestock production in the West African savanna. Journal of Agricultural Science 145:227-238.

Ewansiha, S. U., Tarawali, S. A, Odunze, A. C. and Iwuafor, E. N. O. (2008). Potential contribution of lablab residues to maize production in moist savanna of West Africa. Journal of Sustainable Agriculture 32 (3):393-406.

Fakorede, M. A. B., Badu-Apraku, B., Kamara, A. Y., Menkir, A. And Ajala, S. O. (2003). Maize revolution in West and Central Africa. In : Badu-Apraku, B., Fakorede, M. A. B., Ouedraogo, M., Carsky, R. J. and Menkir, A. (Eds). Strategy for sustainable maize production in West and Central Africa. Proceedings of a regional maize workshop. IITA-Cotonou, Benin Republic, 14-18 May 1997, WECAMA/IITA. pp. 3-15.

IITA 1982. Automated and semi-automated methods for soil and plant analysis. Manual Series 7. (International Institute of Tropical Agriculture: Ibadan, Nigeria).

IITA. (2006). Maize. Accessed January 13, 2007 from http://www.iitaresearch.org.

Iwuafor, E. N. O. and Odunze, A. C. (2000). Performance of selected legume cover crops in an arid zone of Nigeria. In: Carsky, R. J., Eteka, A. C., Keatinge, J. D. H. and Manyong, V. M. (eds). Cover crops for Natural Resource Management in West Africa. Proceedings of a workshop held at Cotonou, Republic of Benin, 26-29 October 1999. International Institute of Tropical Agriculture: Ibadan, Nigeria. pp. 209-213.

Kamara, A. Y., Menkir, A., Ajala, S. O. and Kureh, I. (2005). Performance of diverse maize genotypes under nitrogen deficiency in the northern Guinea savanna of Nigeria. Experimental Agriculture 41: 1999-212.

Mortimore, M.J., Singh, B.B., Harris, F., and Blade, S.F. (1997). Cowpea in traditional cropping systems. In: Singh B.B., D.R. Mohan Raj, K.E. Dashiel, and L.E.N. Jackai (eds). Advances in Cowpea Research. Copublication of International Institute of Tropical Agriculture (IITA) and Japan International Research Center for Agricultural Sciences (JIRCAS). IITA, Ibadan, Nigeria, pp 99-113.

Muhr, L., Tarawali, S.A., Peters, M. And Schultze-Kraft, R. (2002). Soil mineral $\mathrm{N}$ dynamics and maize grain yields following Centrosema macrocarpum and Stylosanthes guianensis: effects of different rotations and varying levels of N fertilizer. Field Crops Research 78: 197-209.

NAERLS and NPAFS (2010). National report of agricultural performance survey of 2010 wet season in Nigeria. NAERLS press. $182 \mathrm{p}$.

NAS (1979). Lablab bean. In: Tropical legumes: Resources for the future. National Academy of Sciences: Washington DC. pp. 59-67.

Olufajo, O. O. and Singh, B. B. (2002). Advances in cowpea cropping research. In: Fatokun, C. A., S. A. Tarawali, B. B Singh, P. M. Kormawa, and M. Tamo (eds). Challenges and opportunities for enhancing sustainable cowpea production. Proceedings of the World Cowpea Conference 111, International Institute of Tropical Agriculture (IITA), Ibadan, Nigeria, 4-8 September 2000. IITA, Ibadan, Nigeria, pp 267-277.

Ofori, F. and Stern, W.R. (1987). Relative sowing time and density of component crops in a maize/cowpea intercrop system. Experimental Agriculture 23: 41-52.

SAS Institute Inc. (2008). The SAS system for Windows. Reslease 9.2. SAS Institute Inc., Cary, NC, USA.

Smith, J. W., Naazie, A., Larbi, A., Agyemang, K. and Tarawali, S. A. (1997). Integrated crop-livestock systems in sub-Saharan Africa: an option or an imperative? Outlook on Agriculture 26, 237-246.

Stoop, W. A. (1986). Agronomic management of cereal/cowpea cropping systems for major toposequence land types in the West African savanna. Field Crops Research 14: 301-319. 
Tarawali, S. A. (1994). Evaluating selected forage legumes for livestock and crop production in the subhumid zone of Nigeria. Journal of Agricultural Science 123:55-60.

Terao, T., Watanabe, I., Matsunaga, R., Hakoyama, S., and Singh, B.B. (1997). Agro-physiological constraints in intercropped cowpea: an analysis. In: Singh B.B., D.R. Mohan Raj, K.E. Dashiel, and L.E.N. Jackai (eds).
Advances in cowpea research. Copublication of International Institute of Tropical Agriculture (IITA) and Japan International Research Center for Agricultural Sciences (JIRCAS). IITA, Ibadan, Nigeria, pp 129-140.

Thomas, D. and Sumberg, J. E. (1995). A review of the evaluation and use of tropical forage legumes in sub-Saharan Africa. Agriculture, Ecosystems and Environment 54: 151-163. 